\title{
A Comparative Study of New Aspergillus Strains for Proteolytic Enzymes Production by Solid State Fermentation
}

\author{
Gastón Ezequiel Ortiz, Diego Gabriel Noseda, María Clara Ponce Mora, \\ Matías Nicolás Recupero, Martín Blasco, and Edgardo Albertó \\ Instituto de Investigaciones Biotecnológicas-Instituto Tecnológico de Chascomús (IIB-INTECH), \\ Universidad Nacional de San Martín (UNSAM) and Consejo Nacional de Investigaciones Científicas y Técnicas (CONICET), \\ San Martín, 1650 Buenos Aires, Argentina \\ Correspondence should be addressed to Gastón Ezequiel Ortiz; gas.ortiz@gmail.com
}

Received 30 July 2015; Revised 28 December 2015; Accepted 10 January 2016

Academic Editor: Raffaele Porta

Copyright @ 2016 Gastón Ezequiel Ortiz et al. This is an open access article distributed under the Creative Commons Attribution License, which permits unrestricted use, distribution, and reproduction in any medium, provided the original work is properly cited.

\begin{abstract}
A comparative study of the proteolytic enzymes production using twelve Aspergillus strains previously unused for this purpose was performed by solid state fermentation. A semiquantitative and quantitative evaluation of proteolytic activity were carried out using crude enzymatic extracts obtained from the fermentation cultures, finding seven strains with high and intermediate level of protease activity. Biochemical, thermodynamics, and kinetics features such as optimum $\mathrm{pH}$ and temperature values, thermal stability, activation energy $\left(E_{\mathrm{a}}\right)$, quotient energy $\left(Q_{10}\right), K_{m}$, and $V_{\max }$ were studied in four enzymatic extracts from the selected strains that showed the highest productivity. Additionally, these strains were evaluated by zymogram analysis obtaining protease profiles with a wide range of molecular weight for each sample. From these four strains with the highest productivity, the proteolytic extract of A. sojae ATCC 20235 was shown to be an appropriate biocatalyst for hydrolysis of casein and gelatin substrates, increasing its antioxidant activities in $35 \%$ and $125 \%$, respectively.
\end{abstract}

\section{Introduction}

Proteases constitute a large and complex group of hydrolytic enzymes with important applications in medical, pharmaceutical, biotechnology, leather, detergent, and food industries [1]. They can be synthesized by plants, animals, and microorganisms constituting around $60 \%$ of the worldwide enzyme market [2]. Among such sources, microorganisms present remarkable potential for proteolytic enzymes production due to their extensive biochemical diversity and susceptibility to genetic manipulation [3]. Filamentous fungi have been utilized for the production of diverse industrial enzymes because these organisms exhibit the capacity to grow on solid substrates and secrete a wide range of hydrolyzing enzymes. Particularly, several species of Aspergillus have been exploited as important sources of extracellular enzymes including proteases [4]. According to the state of the art, most of the current scientific knowledge associated with the proteases production by Aspergillus fungus is related to the use of $A$. oryzae and $A$. niger species (Supplementary Data 1 in Supplementary Material available online at http://dx.doi.org/10.1155/2016/3016149). Products of Aspergillus species such as A. niger, A. sojae, and A. oryzae have acquired a Generally Recognized as Safe (GRAS) status from the US Food and Drug Administration, which has approved their use in the food industry [5].

The production of proteases can be performed by solid state fermentation (SSF) and submerged fermentation (SmF) [6]. The application of SSF is of interest for fungi enzymes production due to its advantages in comparison to SmF, such as low fermentation technology, low cost, higher yields and concentration of the enzymes, and reduced waste output $[7,8]$. Furthermore, inexpensive and widely available agricultural solid wastes could be used with the aim of providing nutritional and physical support throughout SSF procedures [9]. The intense demand for industrial proteolytic enzymes requires the search of new strains with high level of protease productivity in order to enhance the enzyme production 
capacity and their applications [2]. In such context, the aim of this work is to expand the range of species and strains of the genus Aspergillus suitable for the production of proteolytic enzymes under solid state fermentation for industrial use.

\section{Materials and Methods}

2.1. State of the Art Analysis. The state of the art for proteases production by Aspergillus was evaluated through a literature search in the Scopus and PubMed database using the following criteria of search: TITLE ((Aspergillus AND Proteases) and Production). The publications nondirectly related to the proteases production were dismissed (Supplementary Data $1)$.

2.2. Microbial Strains. The Aspergillus strains used in this work were (1) A. terreus ICFC 744/11; (2) A. oryzae NRRL 2217; (3) A. awamori NRRL 356; (4) A. flavipes NRRL 295; (5) A. kawachii IFO 4308; (6) Aspergillus sp. ICFC 7/14; (7) A. japonicus NRRL 1782; (8) A. oryzae ICFC 8/12; (9) A. giganteus NRRL 10; (10) A. rhizopodus NRRL 6136; (11) A. sojae NRRL 5595; and (12) A. sojae ATCC 20235. Such strains are conserved in the IIB-INTECH Collection of Fungal Cultures (ICFC), reference in the WDCM database: WDCM 826. All the strains were periodically propagated and maintained on potato dextrose agar slants.

2.3. Inoculum Preparation. In order to produce conidia for inoculation of the main cultures, the strains were grown on agar-plates containing sugarcane molasses $(45 \mathrm{~g} / \mathrm{L})$, peptone $(18 \mathrm{~g} / \mathrm{L}), \mathrm{NaCl}(5 \mathrm{~g} / \mathrm{L}), \mathrm{KCl}(0.5 \mathrm{~g} / \mathrm{L}), \mathrm{FeSO}_{4} \cdot 7 \mathrm{H}_{2} \mathrm{O}(15 \mathrm{mg} / \mathrm{L})$, $\mathrm{KH}_{2} \mathrm{PO}_{4} \quad(60 \mathrm{mg} / \mathrm{L}), \quad \mathrm{MgSO}_{4} \quad(50 \mathrm{mg} / \mathrm{L}), \quad \mathrm{CuSO}_{4} \cdot 5 \mathrm{H}_{2} \mathrm{O}$ $(15 \mathrm{mg} / \mathrm{L}), \mathrm{MnSO}_{4}(15 \mathrm{mg} / \mathrm{L})$, and agar $(20 \mathrm{~g} / \mathrm{L})$. Plates were incubated at $28^{\circ} \mathrm{C}$ until sporulation. Conidia were harvested from the plates by the addition of $5 \mathrm{~mL}$ of $0.08 \%$ $(\mathrm{w} / \mathrm{v})$ Tween 80 . The number of conidia/mL in the conidia suspension was determined using Neubauer cell-counting chamber.

2.4. Culture Conditions. Erlenmeyer flasks $(250 \mathrm{~mL})$ containing $10 \mathrm{~g}$ of wheat bran with a homogeneous particle size of $2000 \mu \mathrm{m}$ in average were moistened at $110 \%$ with Czapek-Dox medium corresponding to 0.96 units of water activity (Supplementary Data 2). The flasks with the sterile culture substrate (sterilization conditions, $121^{\circ} \mathrm{C}$ for $20 \mathrm{~min}$ ) were inoculated with $10^{6}$ conidia/g of dry substrate (gds) and incubated at $28^{\circ} \mathrm{C}$ in a moist chamber for 2,4 , and 6 days.

2.5. Enzyme Recovery. Enzymes produced were recovered by the addition of $10 \mathrm{~mL} / \mathrm{gds}$ of distilled water into each culture flask and mixing in a shaker at $250 \mathrm{rpm}, 28^{\circ} \mathrm{C}$, for $30 \mathrm{~min}$. Then, the mixtures were clarified by filtration through cotton followed by centrifugation at $2000 \times \mathrm{g}, 4^{\circ} \mathrm{C}$, for $20 \mathrm{~min}$. The clarified supernatants were used for the following analysis.

2.6. Semiquantitative Determination of Proteolytic Activity by Agar-Plate Assay. A semiquantitative determination of proteolytic activity was carried out at different values of $\mathrm{pH}$ by the agar-plate diffusion assay according to the technique described by Heerd et al. [5]. Agar-plates were prepared with $1.5 \%(\mathrm{w} / \mathrm{v})$ agar and $1.5 \%(\mathrm{w} / \mathrm{v})$ skim milk as substrate. Both agar and skim milk were dissolved in $0.1 \mathrm{M}$ Tris- $\mathrm{HCl}$ buffer in order to adjust and maintain the $\mathrm{pH}$ between 6 and 9. Wells of $4 \mathrm{~mm}$ diameter were punched in the solid media and loaded with $20 \mu \mathrm{L}$ crude enzymatic extracts. After $18 \mathrm{~h}$ incubation at $30^{\circ} \mathrm{C}$, the milk agar-plates were stained with Coomassie Brilliant Blue G-250 for $20 \mathrm{~min}$. The diameter of the halos $(D)$ corresponding to the zone of milk degradation was converted to $\log _{10}$ by (1) and reported as hydrolysis index $\left(\log _{10} \mathrm{~mm}^{2}\right)$ [5]:

$$
\begin{aligned}
& \log _{10} \text { adjusted zone area } \\
& \quad=\log _{10}\left[\left(\frac{D}{2}\right)^{2} \pi-\left(\frac{4.0}{2}\right)^{2} \pi\right] .
\end{aligned}
$$

Semiquantitative determination was performed by means of 2 independent assays. Proteolytic activity values from different crude extracts were evaluated by Multifactorial ANOVA and cluster analysis using the statistical software Statgraphics Centurion XVII trial version (Supplementary Data 3).

2.7. Quantitative Analysis of Proteolytic Activity. Protease activity was quantitatively measured using azo-casein assay according to Cavello et al. [10], with modifications. Reaction mixture containing $20 \mu \mathrm{L}$ of enzyme extract diluted in $0.1 \mathrm{M}$ Tris- $\mathrm{HCl}$ buffer (pH: 8) (buffer T) and $50 \mu \mathrm{L}$ of $1 \%(\mathrm{w} / \mathrm{v})$ azo-casein solution in buffer $\mathrm{T}$ was incubated for $60 \mathrm{~min}$ at $37^{\circ} \mathrm{C}$ in thermocycler machine. Reaction was stopped with the addition of $100 \mu \mathrm{L}$ of $10 \%(\mathrm{v} / \mathrm{v})$ trichloroacetic acid. The mixture was kept at room temperature for $15 \mathrm{~min}$ and then centrifuged at $2000 \times \mathrm{g}, 20^{\circ} \mathrm{C}$, for $10 \mathrm{~min}$. Finally, $50 \mu \mathrm{L}$ of each sample was diluted by addition of $50 \mu \mathrm{L}$ of $1 \mathrm{M} \mathrm{NaOH}$ solution and absorbance was measured at $415 \mathrm{~nm}$ with a microplate spectrophotometer. All determinations were performed in duplicate and a heat-inactivated enzyme extract was used for blank. One unit of proteolytic activity (U) was defined as the amount of enzyme that produces an increase of 0.1 units in the absorbance at $415 \mathrm{~nm}$ per min under test conditions. Azocasein was synthesized as described by Riffel et al. [11].

2.8. Effect of Temperature and $p H$ on Proteolytic Activity. The optimal $\mathrm{pH}$ and temperature for crude enzymatic extracts were determined employing a central composite design (CCD) with four axial points and three central points. In order to maximize the variability, the experiments were randomized and performed as shown in Supplementary Data 4. Enzymatic extracts corresponding to 2 days of fermentation were normalized to $30 \mathrm{U} / \mathrm{mL}$ and incubated at different temperature and $\mathrm{pH}$ values during $1 \mathrm{~h}$. For this, the enzymatic extracts were diluted with $0.1 \mathrm{M}$ maleate buffer or $0.1 \mathrm{M}$ Tris$\mathrm{HCl}$ to adjust the $\mathrm{pH}$ to lower or higher values than 7.0, respectively. The protease activity was determined using the 
azo-casein method and the second-order model represented by (2) was used to describe this response:

$$
Y=\beta_{0}+\sum_{i=1}^{n} \beta_{i} x_{i}+\sum_{i=1}^{n-1} \sum_{j=i+1}^{n} \beta_{i j} x_{i} x_{j},
$$

where $Y$ is the estimated response, $\beta_{0}$ is the constant term, $i$ and $j$ have values from 1 to the number of variables $(n)$, $\beta_{i}$ is the linear coefficient, $\beta_{i j}$ is the quadratic coefficient, and $x_{i}$ and $x_{j}$ are the coded independent variables. The coefficient of determination $R^{2}$ and the $F$ value from analysis of variance (ANOVA) were used to confirm the quality of the model. Relationships between the responses and variables were evaluated using Statgraphics Centurion XVII software trial version.

2.9. Enzymatic Stability. The proteolytic stability was analyzed by incubating the crude extracts under optimal $\mathrm{pH}$ and temperature values at different periods of time before conducting enzymatic activity determination by azo-casein method. Due to the complexity of the reaction occurring during inactivation, several equations have been proposed to model this kinetic. In this work, a first-order kinetic model (3) was selected to represent the residual enzyme activity $\left(A / A_{0}\right)$ at time $(t, \mathrm{~min})$. The parameter $k\left(\mathrm{~min}^{-1}\right)$ is the rate constant of the reaction under assay conditions:

$$
\frac{A}{A_{0}}=e^{-k t} \text {. }
$$

2.10. SDS-PAGE and Zymogram Analysis. SDS-PAGE electrophoresis was performed according to the technique described by Laemmli [12]. The enzyme extracts were diluted in loading buffer without DDT to a final concentration of $10 \mathrm{U} / \mathrm{mL}$. A volume of $20 \mu \mathrm{L}$ of each sample was loaded on a $10 \%(\mathrm{v} / \mathrm{w})$ separating SDS-PAGE gel by duplicate in symmetric disposition. The electrophoresis was conducted at $160 \mathrm{~V}$ and $4^{\circ} \mathrm{C}$ during $1 \mathrm{~h}$. After that, the gel was cut in halves, keeping one for the zymogram and staining the other with colloidal Coomassie Brilliant Blue G-250 [13]. Zymography analysis was performed according to Cavello et al. [14] with slight modifications. Briefly, the gel was submerged in $100 \mathrm{mM}$ Tris- $\mathrm{HCl}$ buffer ( $\mathrm{pH}$ 8.0) (buffer T) containing 2.5\% Triton X-100 during $60 \mathrm{~min}$, with constant agitation, and then washed three times with buffer T. Finally, the gel was incubated with $1 \%(\mathrm{w} / \mathrm{v})$ casein in buffer $\mathrm{T}$ at $30^{\circ} \mathrm{C}$ for $60 \mathrm{~min}$ and then stained with Coomassie Brilliant Blue R-250. The development of clear bands on the blue background of the gel indicated the presence of protease activity. The molecular weight of proteolytic enzymes was estimated through densitometry analysis using Image J software $1.44 \mathrm{p}$ version [15].

2.11. Determination of Activation Energy and Temperature Quotient $\left(Q_{10}\right)$. Activation energy $\left(E_{\mathrm{a}}\right)$ values of the proteases produced by Aspergillus strains were calculated by incubating enzyme extracts, under optimal $\mathrm{pH}$ condition, with $1 \%$ azocasein at several temperatures ranging from 30 to $50^{\circ} \mathrm{C}$.
The dependence of the rate constants with temperature was assumed to follow Arrhenius Law (4) and $E_{\mathrm{a}}$ was calculated from the slope of the plot of 1000/T versus $\ln$ (protease activity), where $E_{\mathrm{a}}=-$ slope $\times R, R$ (gas constant) $=8.314$ $(\mathrm{J} / \mathrm{K} \cdot \mathrm{mol})$, and $T$ is the absolute temperature in Kelvin $(\mathrm{K})$ [16]. The temperature quotient $\left(Q_{10}\right)$ values of Aspergillus proteases were determined using (5) [17]:

$$
\begin{aligned}
\ln (\text { Activity }) & =\ln (A)-\frac{E_{\mathrm{a}}}{R} \times \frac{1}{T}, \\
Q_{10} & =\operatorname{antilog} \times e^{-\left(E_{\mathrm{a}} \times 10\right) / R T^{2}} .
\end{aligned}
$$

2.12. Kinetics Parameters $K_{m}$ and $V_{\max }$. Kinetics parameters $K_{m}$ and $V_{\max }$ of the proteases produced by Aspergillus strains were determined by incubating crude extracts, under optimal $\mathrm{pH}$ and temperature values, with azo-casein over the concentration range $1.0-10.0 \mathrm{mg} / \mathrm{mL}$. Protease activity of each extract was quantitatively measured as described in Section 2.7. The Michaelis-Menten constant $\left(K_{m}\right)$ and maximum velocity $\left(V_{\max }\right)$ values were calculated using the GraphPad Prism $4^{\circ}$ trial version. The values employed in the nonlinear regression are shown in Supplementary Data 7.

2.13. Preparation of Protein Hydrolysates. For the production of protein hydrolysates, the enzyme concentration of a selected crude extract was adjusted to $400 \mathrm{U}$ per gram of dry substrate (U/gds) according to its proteolytic activity established previously. Gelatin and casein substrates were suspended in buffer citrate phosphate $0.1 \mathrm{M}$ to a final concentration of $1.0 \%(\mathrm{w} / \mathrm{v})$. A total of $15 \mathrm{~mL}$ of each mixture was distributed in $50 \mathrm{~mL}$ Erlenmeyer flasks and incubated in a water bath shaker operating at $50 \mathrm{rpm}$. The hydrolysis was performed at the optimal temperature and $\mathrm{pH}$ values of the enzyme extract during $120 \mathrm{~min}$. Aliquots $(0.5 \mathrm{~mL})$ of each mixture were taken at regular intervals and inactivated in a water bath at $100^{\circ} \mathrm{C}$ for $15 \mathrm{~min}$. A volume of $0.1 \mathrm{~mL}$ was reserved to determine the degree of hydrolysis. The remaining volume $(0.4 \mathrm{~mL})$ was centrifuged at $12,500 \times \mathrm{g}$ in Eppendorf MiniSpin ${ }^{\circ}$ for $10 \mathrm{~min}$ for separating the soluble peptides from nonhydrolyzed proteins. The supernatants were collected to determine the antioxidant activities.

2.14. Determination of Antioxidant Activities. The antioxidant activity of the protein hydrolysates was determined by the DPPH radical-scavenging method as described by Bougatef et al. [18] with adaptations for microplate assay. A volume of $50 \mu \mathrm{L}$ of the diluted hydrolysates was mixed with $50 \mu \mathrm{L}$ of $99.5 \%$ ethanol and $30 \mu \mathrm{L}$ of $0.02 \% \mathrm{DPPH}$ in $99.5 \%$ ethanol. The mixtures were kept at room temperature in the dark for $60 \mathrm{~min}$, and the reduction of the DPPH radical was measured at $540 \mathrm{~nm}$ using a microplate reader Bio-Rad Benchmark ${ }^{\circ}$. The DPPH radical-scavenging activity was calculated using

$$
\begin{aligned}
& \text { Radical scavening activity (\%) } \\
& =\frac{\text { Control } \mathrm{Abs}_{540 \mathrm{~nm}}-\text { Sample } \mathrm{Abs}_{540 \mathrm{~nm}}}{\text { Control } \mathrm{Abs}_{540 \mathrm{~nm}}} \times 100 \% .
\end{aligned}
$$




\begin{tabular}{|c|c|c|c|c|c|c|c|c|c|c|c|c|}
\hline & & & & & & & & & & & & \\
\hline & 2.5 & 2. & & 2.2 & 2.1 & 2.0 & 1.8 & 1.7 & 1. & .6 & 1.5 & 1.3 \\
\hline & & & ay 2 & & & $\mathrm{Da}$ & y 4 & & & & ay 6 & \\
\hline rain & $\mathrm{pH} 6$ & $\mathrm{pH} 7$ & $\mathrm{pH} 8$ & $\mathrm{pH} 9$ & $\mathrm{pH} 6$ & \begin{tabular}{|l|l|}
$6 \mathrm{pH} 7$ \\
\end{tabular} & $\mathrm{pH} 8$ & $\mathrm{pH} 9$ & $\mathrm{pH} 6$ & pH7 & $\mathrm{pH} 8$ & $\mathrm{pH} 9$ \\
\hline 1 & $\mathrm{NA}$ & NA & NA & NA & NA & $\mathrm{NA}$ & NA & NA & NA & NA & $\mathrm{NA}$ & NA \\
\hline 2 & 2.28 & 00 & 2.22 & 2.15 & 2.33 & 2.08 & 2.22 & 2.00 & 2.33 & 2.08 & 2.22 & 2.22 \\
\hline 3 & 1.58 & A & NA & NA & 1.92 & \begin{tabular}{|l}
1.58 \\
\end{tabular} & 1.41 & 1.71 & 1.82 & 1.58 & 1.41 & 1.4 \\
\hline 4 & 2.22 & 1.82 & 2.00 & 1.71 & 2.43 & $\begin{array}{ll}3 & 2.08 \\
\end{array}$ & 2.15 & 1.82 & $\mid 2.43$ & 2.15 & 2.22 & 1.5 \\
\hline 5 & 1.58 & NA & NA & 1.20 & 2.00 & $\begin{array}{l}1.82 \\
\end{array}$ & NA & 1.20 & $\mid 1.92$ & 1.71 & NA & 1. \\
\hline 6 & NA & NA & NA & NA & 1.58 & $3 \mathrm{NA}$ & NA & NA & 1.58 & NA & NA & $\mathrm{N}$ \\
\hline 7 & NA & NA & NA & NA & 1.41 & NA & NA & NA & 1.58 & NA & NA & $\mathrm{N}$ \\
\hline 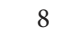 & 2.33 & 58 & 2.15 & 2.00 & 2.4 & 2.22 & 2.28 & 1.92 & 2.48 & 2.28 & 2.28 & 2.2 \\
\hline 9 & 2.28 & 1.92 & 1.92 & 2.15 & 2.22 & $\begin{array}{ll}2 & 1.82 \\
\end{array}$ & 1.92 & 1.92 & 2.15 & 1.71 & 1.82 & 1.7 \\
\hline & 1.9 & 58 & 1.58 & 1.58 & 2.08 & \begin{tabular}{ll|}
3 & 1.71 \\
\end{tabular} & 1.71 & 1.71 & 2.08 & 1.71 & 1.82 & 1.7 \\
\hline & 2.22 & .71 & 1.92 & 1.82 & 2.22 & $\begin{array}{ll}2 & 1.71 \\
\end{array}$ & 1.82 & 1.58 & 2.22 & 1.71 & 1.82 & 1.5 \\
\hline & & 2.22 & 2.22 & 2.08 & 2.48 & $\begin{array}{ll}32.33 \\
\end{array}$ & 2.33 & 2.15 & $\mid 2.48$ & 2.33 & 2.38 & 2.33 \\
\hline
\end{tabular}

(a)

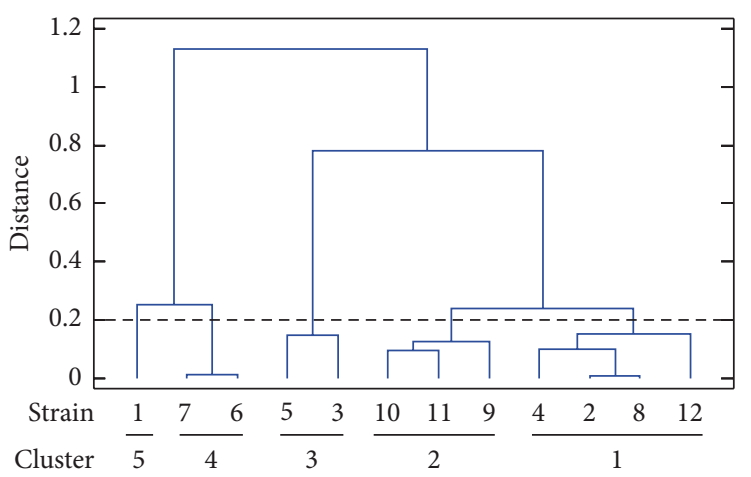

(b)

FIGURE 1: Semiquantitative analysis of proteolytic activity from Aspergillus spp. extracts. Protease activity was semiquantitatively analyzed for different values of $\mathrm{pH}$ from crude extracts of Aspergillus ssp. cultures obtained by solid state fermentation. (a) Proteolytic activity values expressed by the hydrolysis index $\left(\log _{10} \mathrm{~mm}^{2}\right)$. The values correspond to the average of two independent studies. NA: no activity. (b) Dendrogram constructed from the proteolytic activities using median method and squared Euclidean distance. Distance of 0.2 indicates the cut-line for cluster designation. For strain reference numbers see Section 2.2.

2.15. Determination of the Degree of Hydrolysis. The degree of hydrolysis of the protein hydrolysates was determined according to the method described by Adler-Nissen [19]. Mixtures of $0.5 \mathrm{~mL}$ of diluted hydrolysates or $0.825 \mathrm{mmol} / \mathrm{L}$ standard cysteine amino acid and $0.250 \mathrm{~mL}$ of $0.01 \%(\mathrm{w} / \mathrm{v})$ TNBSA in $0.1 \mathrm{M}$ sodium bicarbonate $\mathrm{pH} 8.5$ were incubated for $30 \mathrm{~min}$ at $37^{\circ} \mathrm{C}$. A volume of $200 \mu \mathrm{L}$ of each mixture was taken and the absorbance measured at $415 \mathrm{~nm}$ in a Bio-Rad Benchmark microplate reader. Degree of hydrolysis (DH) values were calculated using

$$
\begin{aligned}
& \text { Cysteine- } \mathrm{NH}_{2}\left(\frac{\mathrm{meqv}}{\mathrm{g}}\right) \\
& =X \times V \times f \\
& \times \frac{\text { Sample Abs } \mathrm{Al15}_{\mathrm{nm}}-\text { Blank } \mathrm{Abs}_{415 \mathrm{~nm}}}{\text { Standard } \mathrm{Abs}_{415 \mathrm{~nm}}-\text { Blank } \mathrm{Abs}_{415 \mathrm{~nm}}} \\
& \times 0.82 \mathrm{meqv} / \mathrm{L} \text {, } \\
& h=\frac{\left[\text { Cysteine }-\mathrm{NH}_{2}\right]-\beta}{\alpha}, \\
& \mathrm{DH}(\%)=\frac{h}{h_{\mathrm{tot}}} \times 100 \% \text {, }
\end{aligned}
$$

where cysteine- $\mathrm{NH}_{2}$ is milliequivalents of cysteine amine groups per gram of protein; $X$ is mass of sample protein in gram (g); $V$ is the reaction volume in liter (L); and $f$ is dilution factor. The value $h$ is the number of hydrolyzed peptide bonds and $h_{\text {tot }}$ is the total number of peptide bonds per protein equivalent. The values $\alpha, \beta$, and $h_{\text {tot }}$ for casein and gelatin are $\alpha=1.039, \beta=0.383$, and $h_{\text {tot }}=8.2$ and $\alpha=0.796$, $\beta=0.457$, and $h_{\mathrm{tot}}=11.1$, respectively [20].

\section{Results and Discussion}

3.1. Semiquantitative Determination of Proteolytic Activity. To evaluate the capability of Aspergillus strains for proteases production, crude enzymatic extracts obtained by SSF were semiquantitatively analyzed for total proteolytic activity at different $\mathrm{pH}$ values by agar-plate diffusion assay. In this study the diameters of proteolysis halos were adjusted as indicated in Section 2.6 to report the enzymatic activity index. Such values were employed to compare the strains through multifactorial analysis of variance (ANOVA) (Supplementary Data 3). Wheat bran was chosen as the screening substrate because it possesses a suitable carbon to nitrogen ratio $(\mathrm{C}: \mathrm{N})$ and water absorption index, necessary for an appropriate growth and protease production as was reported by Soares de Castro et al. [21, 22]. Analysis of variance revealed that most of the evaluated strains registered significantly higher proteolytic activity at days 4 and 6 of fermentation and with a $\mathrm{pH}$ value of 6.0 (Figure 1(a)). Furthermore, the cluster analysis (Figure 1(b)) revealed the presence of five homogeneous clusters of strains based on its enzymatic activity. Cluster 1, which included A. sojae ATCC 20235, A. oryzae ICFC 8/12, A. oryzae NRRL 2217, and A. flavipes NRRL 295, showed a high protease activity throughout the tested $\mathrm{pH}$ range, while cluster 2 , formed by $A$. giganteus NRRL 10, A. sojae NRRL 5595, and A. rhizopodus NRRL 6136, presented intermediate values of proteolytic activity in the $\mathrm{pH}$ range 7.0-9.0, displaying an increase in the activity at $\mathrm{pH}$ 6.0. Furthermore, cluster 3 (A. kawachii IFO 4308 and $A$. awamori NRRL 356 strains) exhibited a reduced proteolytic activity throughout the $\mathrm{pH}$ range for days 4 and 6 . Cluster 4 (Aspergillus sp. ICFC 7/14 and A. japonicus NRRL 1782 strains) showed very low proteolytic activity at pH 6.0 on days 4 and 6 . Finally, cluster 5 did not record proteolytic activity. Based on these results it can be concluded that crude 


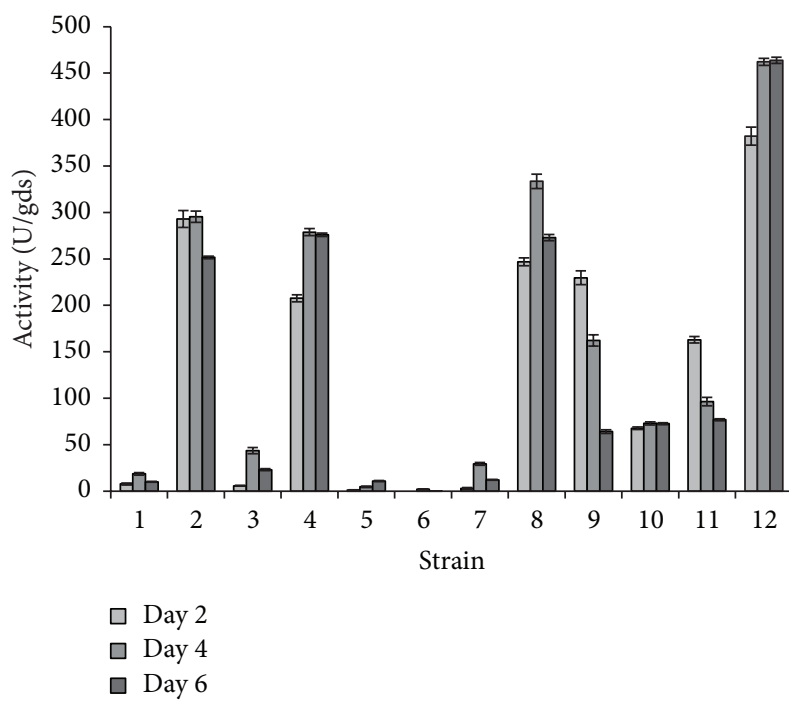

(a)

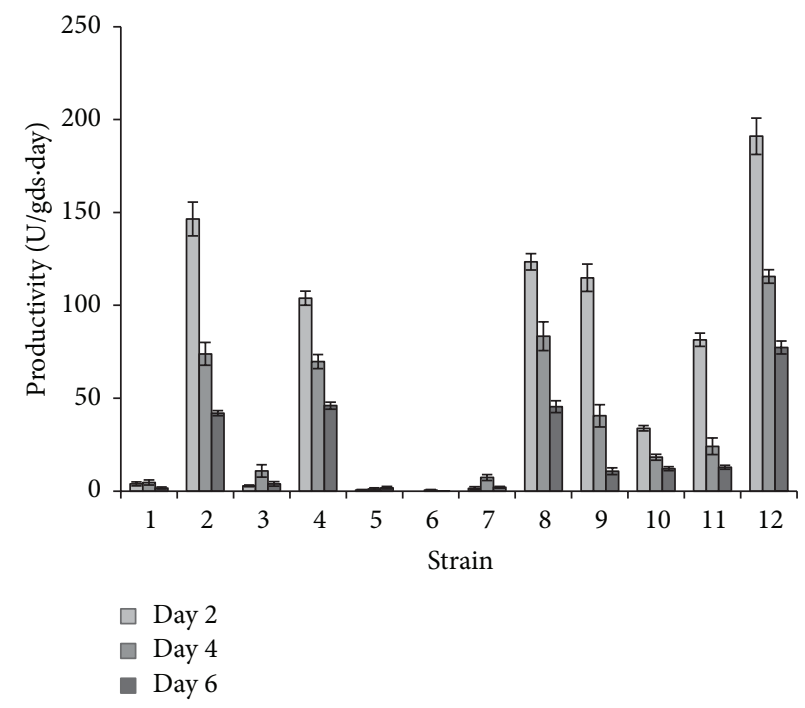

(b)

Figure 2: Protease production and productivity from Aspergillus spp. extracts. (a) Protease production expressed as proteolytic activity for 3 different periods of culture. (b) Proteolytic productivity during fermentation process. Experiments were performed in triplicate and error bars represent the standard deviation. For strain reference numbers see Section 2.2.

extracts from strains of cluster 1 provided the highest level of protease activity. It should be mentioned that the strains of such cluster, A. flavipes NRRL 295 and A. sojae ATCC 20235, do not possess scientific reports for proteolytic enzymes production. However, it is well known that $A$. sojae and $A$. oryzae are employed industrially for commercial production of proteases [2]. On the other hand, the A. sojae NRRL 5595, A. giganteus NRRL 10, and A. rhizopodus NRRL 6136 strains (cluster 2) provided intermediate level of proteolytic activity. It is important to highlight that the last two species were not previously reported for protease production.

3.2. Proteolytic Activity and Productivity Analysis. In order to validate the results achieved previously a quantitative study of the proteolytic activity and enzymatic productivity was conducted. As shown in Figure 2(a) the strains belonging to cluster 1 (Figure 1(b)) presented the highest level of proteolytic activity. In this cluster, the A. sojae ATCC 20235 and A. flavipes NRRL 295 showed a similar protease production pattern in which the activity increased and remained constant during the culture suggesting an adequate stability of the crude extracts, whereas $A$. oryzae ICFC $8 / 12$ and $A$. oryzae NRRL 2217 exhibited a decrease in the proteolytic activity on day 6 of incubation, which suggested certain instability of these enzymes. Furthermore, A. giganteus NRRL 10, A. rhizopodus NRRL 6136, and A. sojae NRRL 5595 that formed cluster 2 (Figure 1(b)) showed a lower enzyme activity which decreased over the culture course for A. giganteus NRRL 10 and $A$. sojae NRRL 5595, but remained stable with a low value for A. rhizopodus NRRL 6136 suggesting an appropriate enzymatic stability for this strain. On the other hand, the protease production profile observed for $A$. giganteus NRRL 10, A. rhizopodus NRRL 6136, and A. sojae NRRL 5595 is similar to the production profile reported by Soares de Castro et al. for
A. oryzae LBA01 and A. niger LB02, two species well known for their good productivity of proteolytic enzymes $[3,23]$. In addition, maximum protease productivity was registered for day 2 of fermentation for strains of clusters 1 and 2 (Figures 2 (b) and $1(\mathrm{~b})$ ). These results confirmed that strains from cluster 1 presented the highest level of protease production and demonstrated that maximum productivity was achieved after a short fermentation time. On the other hand, and according to the results obtained with the semiquantitative analyses, crude extracts from the strains of the clusters 3, 4, and 5 showed the lowest proteolytic activity (Figures 2(a) and 1(b)) and productivity (Figure 2(b)).

\subsection{Influence of Temperature and $\mathrm{pH}$ on Proteolytic Activity.} The optimal temperature of fungal proteases ranged between 35 and $50^{\circ} \mathrm{C}$ with few exceptions and the optimum $\mathrm{pH}$ values for acid and alkaline proteolytic enzymes range between 2.0-6.0 and 8.0-11.0, respectively, while optimal $\mathrm{pH}$ for neutral proteases and metalloproteases ranges from 6 to 8 [2]. Therefore, in order to determine the optimum $\mathrm{pH}$ and temperature of proteases from the strains with higher proteolytic productivity, A. flavipes NRRL 295, A. oryzae ICFC 8/12, A. giganteus NRRL 10, and A. sojae ATCC 20235, we performed a central composite design with four axial points as was described in Section 2.8 and the results were analyzed by ANOVA to confirm the quality of each model and the adequacy of these models was validated by three verification trials (Supplementary Data 4). It should be mentioned that $A$. oryzae ICFC $8 / 12$ was selected as a control strain for this analysis since it is a well-studied strain. As shown in Figure 3, enzymatic extracts from strains A. oryzae ICFC 8/12 and A. sojae ATCC 20235 presented maximum proteolytic activity in a $\mathrm{pH}$ range of 6.0 to 6.8 and a temperature range between 43 and $53^{\circ} \mathrm{C}$, suggesting 

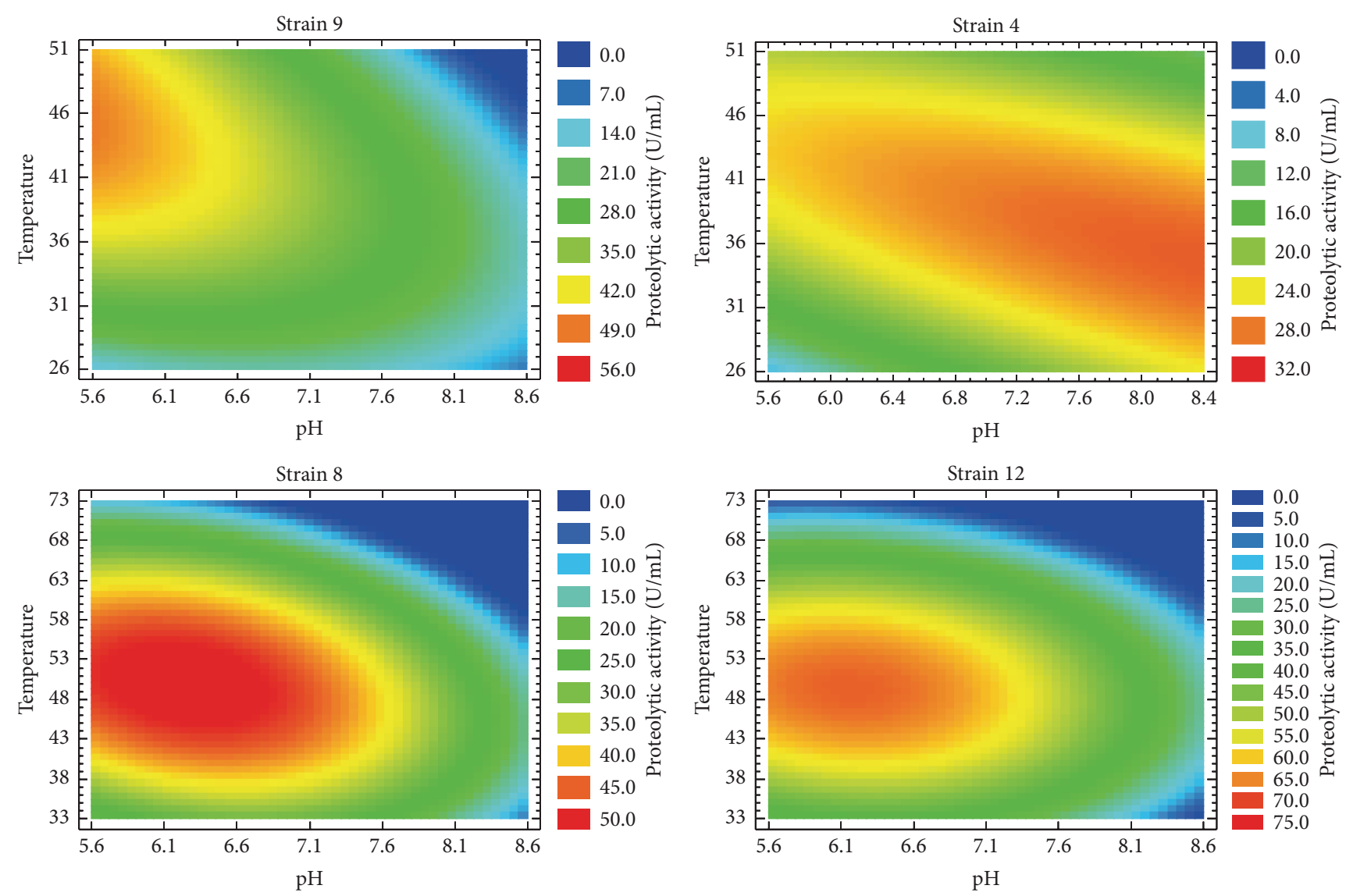

FIGURE 3: Effect of $\mathrm{pH}$ and temperature on proteolytic activity. Enzyme activities analyzed through central composite design. The dependence of the activity with $\mathrm{pH}$ and temperature is represented as a contour plot. Red and blue colors indicate the values of maximum and minimum activities, respectively. For strain reference numbers see Section 2.2 .

that these extracts would be composed mainly of neutral and thermophilic proteases. In this sense, the production of neutral proteolytic enzymes had previously been reported for A. oryzae NRRL 2220 and A. sydowii [24, 25]. Furthermore, we determined that $A$. flavipes NRRL 295 had maximum activity around $\mathrm{pH} 8.4$ and in the temperature range 32$43^{\circ} \mathrm{C}$, suggesting the presence of alkaline and mesophilic proteases in such extract. In this respect, proteases with these biochemical features were previously described for $A$. tamarii [26]. Meanwhile, A. giganteus NRRL 10 exhibited maximum activity around $\mathrm{pH} 5.6$ and with a temperature range $41-51^{\circ} \mathrm{C}$, indicating that the extract would be mainly composed of acidic and thermophilic proteases. In this sense, the production of enzymes with similar characteristics has previously been reported for A. oryzae LBA01 and MTCC $5341[23,27]$. In accordance with the results obtained from the semiquantitative analysis (Figure 1), A. sojae ATCC 20235, A. oryzae ICFC 8/12, and A. flavipes NRRL 295 showed proteolytic activity over the broad $\mathrm{pH}$ range 5.6-8.4, while A. giganteus NRRL 10 presented higher activity at acidic $\mathrm{pH}$ values.

3.4. Thermal and $p H$ Stability of Aspergillus Proteases. The stability of enzymes appears as an important critical aspect to conduct industrial application. Therefore, thermal and $\mathrm{pH}$ stability of proteolytic extracts were evaluated under the optimal conditions previously determined. Figure 4 and Table 3 show the decay curves of proteolytic activity for the evaluated enzymatic extracts. The extracts from A. sojae ATCC 20235 and A. flavipes, tested under $\mathrm{pH} 6.4$ and $48^{\circ} \mathrm{C}$ and $\mathrm{pH} 8.4$ and $36^{\circ} \mathrm{C}$, respectively, presented similar stability with an inactivation constant of $0.003 \mathrm{~min}^{-1}$ and a half-life time of around $215 \mathrm{~min}$. These enzymes resulted as more stable than other proteases previously reported for Aspergillus species such us $A$. clavatus strains ES1 (half-life: $30 \mathrm{~min}$ at $50^{\circ} \mathrm{C}$ ) and CCT2759 (half-life: $18 \mathrm{~min}$ at $50^{\circ} \mathrm{C}$ ) [28]. On the other hand, the extract from A. giganteus, analyzed at $\mathrm{pH} 5.6$ and $48^{\circ} \mathrm{C}$ showed a high inactivation constant of $0.021 \mathrm{~min}^{-1}$ and a halflife of about $33 \mathrm{~min}$ reflecting poor level of stability. Proteases from Penicillium sp. showed similar stability properties with a half-life of $30 \mathrm{~min}$ at $45^{\circ} \mathrm{C}$ [29]. Meanwhile, $A$. oryzae ICFC $8 / 12$ which was evaluated under $\mathrm{pH} 6.4$ and $48^{\circ} \mathrm{C}$ exhibited an intermediate stability with an inactivation constant of $0.009 \mathrm{~min}^{-1}$ and a half-life time of $75 \mathrm{~min}$.

3.5. Electrophoresis SDS-PAGE and Zymogram Analysis. The molecular weights of fungal proteases are generally in the range of 20 and $50 \mathrm{kDa}$ [2], with some exception such as low-molecular weight alkaline protease $(6.8 \mathrm{kDa})$ from 


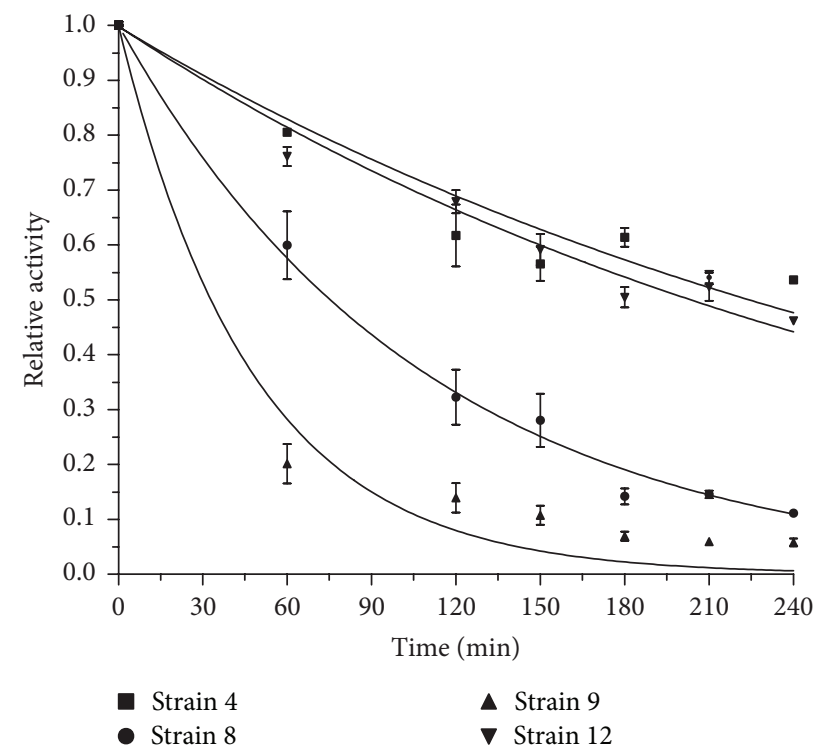

FIgURE 4: Thermal and $\mathrm{pH}$ stability study of protease extracts. Fraction of enzymes remaining active after incubation under optimal conditions. Three independent samples were assayed for each enzymatic extract and error bars represent the standard deviation.

Conidiobolus coronatus [30] and high-molecular weight thiol proteinase $(237 \mathrm{kDa})$ from Humicola lanuginosa UAMH 1623 [31]. Likewise, the diversity in molecular weights of fungal proteases has been used to differentiate the species A. sojae and $A$. oryzae on the basis of specific mobility of alkaline proteases in polyacrylamide gel disc electrophoresis [32]. In order to evaluate the total protein pattern and the taxonomic proteolytic enzyme profile, crude enzymatic extracts corresponding to strains A. sojae ATCC 20235, A. oryzae ICFC 8/12, A. giganteus NRRL 10, and A. flavipes NRRL 295 were analyzed under alkaline condition by polyacrylamide gel electrophoresis and zymogram. Hence, SDS-PAGE analysis (Figure 5) allowed us to distinguish a clear difference between the protein patterns of the four examined strains. Likewise, such patterns presented remarkable bands throughout the whole range of molecular weight $(100-10 \mathrm{kDa})$. Furthermore, as shown in Table 4, A. flavipes NRRL 295 and A. oryzae ICFC $8 / 12$ strains exhibited bands with high proteolytic activity in the range $20-35 \mathrm{kDa}$. These results are in accordance with previous studies that reported an alkaline serine-protease from A. clavatus ES1 with a molecular mass of $32 \mathrm{kDa}$ and an alkaline protease from $A$. terreus with a molecular weight of $37 \mathrm{kDa}[33,34]$. In addition, crude extracts from the strains of A. giganteus and A. sojae presented remarkable active bands with molecular masses in the range $85-95 \mathrm{kDa}$ which was consistent with a high-molecular mass protease $(124 \mathrm{kDa})$ from $A$. fumigatus TKU003 reported by Wang et al. [35]. Chien and coworkers reported the purification, characterization, and cloning of a leucine aminopeptidase (LAP) from A. sojae with an apparent molecular mass of $37 \mathrm{kDa}$ [36]. In this sense, a protease with a similar relative molecular weight could be produced by A. sojae ATCC 20235 (Table 4).
TABLE 1: Activation energy $\left(E_{\mathrm{a}}\right)$ and $Q_{10}$ for azo-casein hydrolysis of the proteolytic extracts from selected Aspergillus strains.

\begin{tabular}{lcccc}
\hline Strain & Temperature range $\left({ }^{\circ} \mathrm{C}\right)$ & $E_{\mathrm{a}}(\mathrm{kJ} / \mathrm{mol})$ & $Q_{10}{ }^{*}$ & $R^{2}$ \\
\hline 4 & $30-40$ & $21.82 \pm 1.43^{\dagger}$ & 1.31 & 0.98 \\
8 & $30-50$ & $38.64 \pm 3.27$ & 1.61 & 0.97 \\
9 & $30-46$ & $31.66 \pm 1.87$ & 1.48 & 0.99 \\
12 & $30-46$ & $29.28 \pm 3.35$ & 1.44 & 0.97 \\
\hline
\end{tabular}

${ }^{*} Q_{10}$ determined using the average temperature range.

${ }^{\dagger}$ Std. error of linear regression coefficient.

3.6. Activation Energy and Temperature Quotient. The activation energies of the proteases produced by Aspergillus strains were determined at the temperature ranges that are indicated in Table 1. The Arrhenius plots for such proteases showed a linear variation with temperature increase, suggesting that these proteolytic enzymes have single conformations up to the transition temperatures (Supplementary Data 5) [16]. As shown in Table 1, the minimal activation energy $(21.82 \mathrm{~kJ} / \mathrm{mol})$ necessary to conduct the hydrolysis of azocasein was obtained for alkaline proteases from A. flavipes NRRL 295. Likewise, the intermediate energies values were obtained for acid proteases from A. sojae ATCC 20235 and A. giganteus NRRL 10. On the other hand A. oryzae ICFC $8 / 12$ presented the highest activation energy $(38.64 \mathrm{~kJ} / \mathrm{mol})$. In this context, Melikoglu and coworkers [16] reported an activation energy of the $36.8 \mathrm{~kJ} / \mathrm{mol}$ for bread protein hydrolysis employing proteases from $A$. awamori in a temperature range of $30-55^{\circ} \mathrm{C}$. This value was similar to those obtained for the strains of A. sojae, A. giganteus, and A. oryzae. On the other hand proteolytic extracts from $A$. niger in a range of $35-50^{\circ} \mathrm{C}$ exhibited activation energies values for azo-casein hydrolysis that ranged from 16.32 to $19.48 \mathrm{~kJ} / \mathrm{mol}$ [17]. These values are similar to that obtained from the strain of $A$. flavipes. To study the effect of temperature on the rate of reaction, we investigated the temperature quotient $\left(Q_{10}\right)$, that is, a measure of the rate of change of a biological or chemical system as a consequence of increasing the temperature by $10^{\circ} \mathrm{C}$. The $Q_{10}$ values of the examined extracts ranged from 1.31 to 1.61 (Table 1 ). Generally enzymatic reactions show $Q_{10}$ values between 1.00 and 2.00 units and any deviation from this value is indicative of involvement of some factor other than temperature in controlling the rate of reaction. Soares de Castro and coworkers reported the $Q_{10}$ values between 1.20 and 1.28 for azo-casein hydrolysis with temperatures between 30 and $60^{\circ} \mathrm{C}$ [17]. The maximum value of $Q_{10}$ was obtained for proteases from $A$. oryzae ICFC $8 / 12$ reflecting that for every $10^{\circ} \mathrm{C}$ raise in temperature the rate of reaction increased $61 \%$.

3.7. Kinetic Parameters $K_{m}$ and $V_{\max }$. In order to evaluate the kinetics properties of proteolytic enzymes, the parameters $V_{\max }, K_{m}$, and $V_{\max } / K_{m}$ were calculated for each proteases extract under optimal $\mathrm{pH}$ and temperature conditions (Table 2). The maximum catalysis velocity $\left(V_{\max }\right)$ is the amount of enzyme involve in the enzymatic reaction. The $K_{m}$ parameter provides the affinity of enzyme for substrate: a low value of this parameter indicates a higher affinity enzymesubstrate. The ratio $V_{\max } / K_{m}$ is related to the specificity and 
TABLE 2: Kinetics parameters $K_{m}$ and $V_{\text {Max }}$ for proteolytic extracts from selected Aspergillus strains.

\begin{tabular}{lccccc}
\hline Strain & $\begin{array}{c}V_{\text {Max }} \\
(\mathrm{U} / \mathrm{mL})\end{array}$ & $\begin{array}{c}V_{\mathrm{Max}} \\
(\mathrm{U} / \mathrm{gds})\end{array}$ & $\begin{array}{c}K_{m} \\
(\mathrm{mg} / \mathrm{mL})\end{array}$ & $\begin{array}{c}V_{\mathrm{Max}} / K_{m} \\
(\mathrm{U} / \mathrm{mg})\end{array}$ & $\begin{array}{c}V_{\text {Max }} / K_{m} \\
(\mathrm{U} \cdot \mathrm{mL} / \mathrm{mg} \cdot \mathrm{gds})\end{array}$ \\
\hline 12 & $23.38 \pm 1.16^{\dagger}$ & $233.8 \pm 2.1^{\dagger}$ & $1.34 \pm 0.26^{\dagger}$ & $17.45 \pm 0.20^{\dagger}$ & $174.5 \pm 2.0^{\dagger}$ \\
9 & $20.79 \pm 0.98$ & $207.9 \pm 9.8$ & $1.48 \pm 0.26$ & $14.04 \pm 0.18$ & $140.4 \pm 1.8$ \\
8 & $15.51 \pm 0.66$ & $155.1 \pm 6.6$ & $0.86 \pm 0.18$ & $18.03 \pm 0.22$ & $180.3 \pm 2.2$ \\
4 & $4.46 \pm 0.21$ & $44.6 \pm 2.1$ & $0.97 \pm 0.21$ & $4.59 \pm 0.22$ & $45.9 \pm 2.2$ \\
\hline
\end{tabular}

${ }^{\dagger}$ Std. error of nonlinear regression coefficient (Michaelis-Menten kinetics fit).

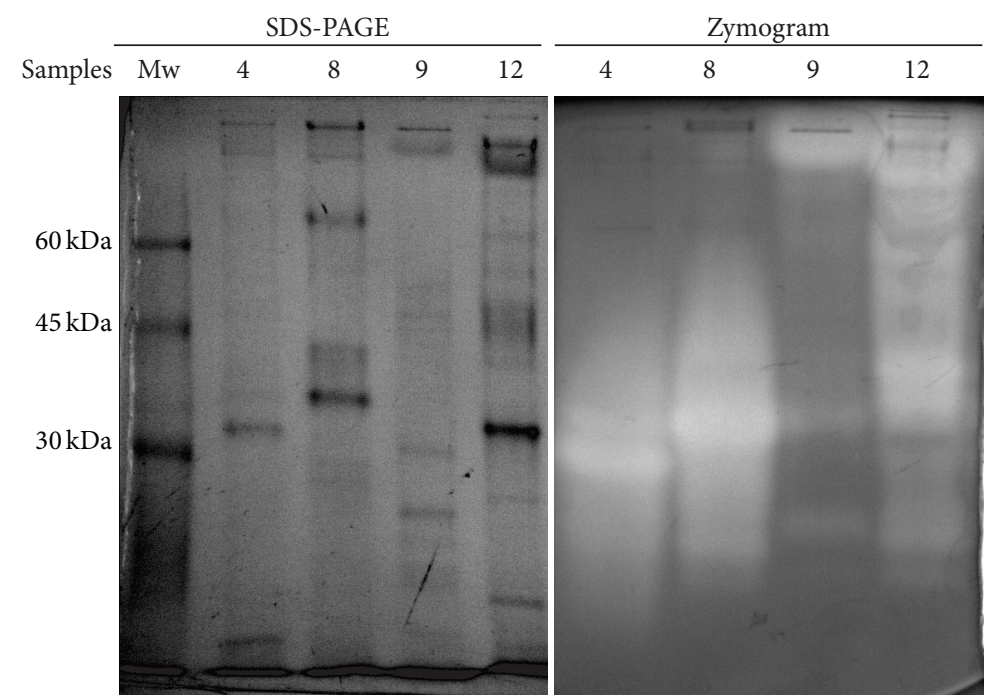

FIgure 5: Analysis of crude extracts by SDS-PAGE electrophoresis and zymogram. Samples: Mw: protein molecular weight marker; 4: $A$. flavipes NRRL 295; 8: A. oryzae ICFC 8/12; 9: A. giganteus NRRL; 10, 12: A. sojae ATCC 20235.

TABLE 3: Inactivation and statistical parameters estimated using a first-order inactivation model (3). Parameter $K$ is the inactivation rate constant and $A_{0}$ is the initial activity. For strain reference numbers see Section 2.2.

\begin{tabular}{lcccc}
\hline & Strain 4 & Strain 8 & Strain 9 & Strain 12 \\
\hline Enz. extract & & & & \\
$\quad A_{0}$ & 0.998 & 1.000 & 0.999 & 0.999 \\
$K$ (min) & 0.003 & 0.009 & 0.021 & 0.003 \\
$\quad$ Half-life (min) & 225.000 & 75.260 & 32.910 & 204.000 \\
Std. error & & & & \\
$\quad A_{0}$ & 0.004 & 0.003 & 0.005 & 0.003 \\
$K$ & 0.000 & 0.000 & 0.001 & 0.000 \\
$R^{2}$ & 0.973 & 0.995 & 0.994 & 0.990 \\
\hline
\end{tabular}

efficiency of enzymes: a high value of this parameter indicates a higher catalytic specificity and efficiency $[37,38]$.

The highest affinity for azo-casein was observed for proteolytic extract from $A$. oryzae ICFC $8 / 12$ with a $K_{m}$ value expected at $0.86 \mathrm{mg} / \mathrm{mL}$, followed by proteases from $A$. flavipes NRRL 295, A. sojae ATCC 20235, and A. giganteus NRRL 10 (Table 2). A wide $K_{m}$ value for azo-casein hydrolysis has been reported. $\mathrm{Li}$ and coworkers reported a $K_{m}$ value of $0.96 \mathrm{mg} / \mathrm{mL}$ for an acid protease from a $A$. oryzae and A. niger fusant strain [4]. Furthermore, Soares de Castro et al. reported a wide range of $K_{m}(0.44-1.92 \mathrm{mg} / \mathrm{mL})$ when A. niger was grown on different substrates [17]. Murthy and Naidu reported a higher $K_{m}$ value $(3 \mathrm{mg} / \mathrm{mL})$ for an alkaline protease from $A$. oryzae growing in solid state fermentation using coffee waste as substrate [39]. The $V_{\max }$ values of the proteolytic extracts ranged between $44.6 \mathrm{U} / \mathrm{gds}$ and $233.8 \mathrm{U} / \mathrm{gds}$ (Table 2). Similar range values were reported by Soares de Castro et al. for $A$. niger grown on different substrates [17]. The highest substrate specificity and catalytic efficiency $\left(V_{\max } / K_{m}\right.$ ratio) was achieved for proteases from $A$. oryzae ICFC 8/12 and A. sojae ATCC 20235 (Table 2); similar values were obtained for proteases from $A$. niger grown on wheat bran [17].

3.8. Hydrolysis Degree and Antioxidant Activity. Proteases from different $A$. oryzae strains have been used in the hydrolysis of whey protein or gelatin with the purpose of obtaining functional peptides with antioxidant activity $[40,41]$. In this context and considering that $A$. sojae ATCC 20235 achieved the highest productivity and exhibited similar biochemical characteristics (Figure 3 ) and casein specificity (Table 2) with respect to $A$. oryzae ICFC 8/12 (control strain), we decided to explore the potentiality of the A. sojae ATCC 20235 proteases for the production of antioxidant peptides from the hydrolysis of casein or gelatin. As shown in Figure 6(a) the degree of hydrolysis $(\mathrm{DH})$ of casein was significantly higher 


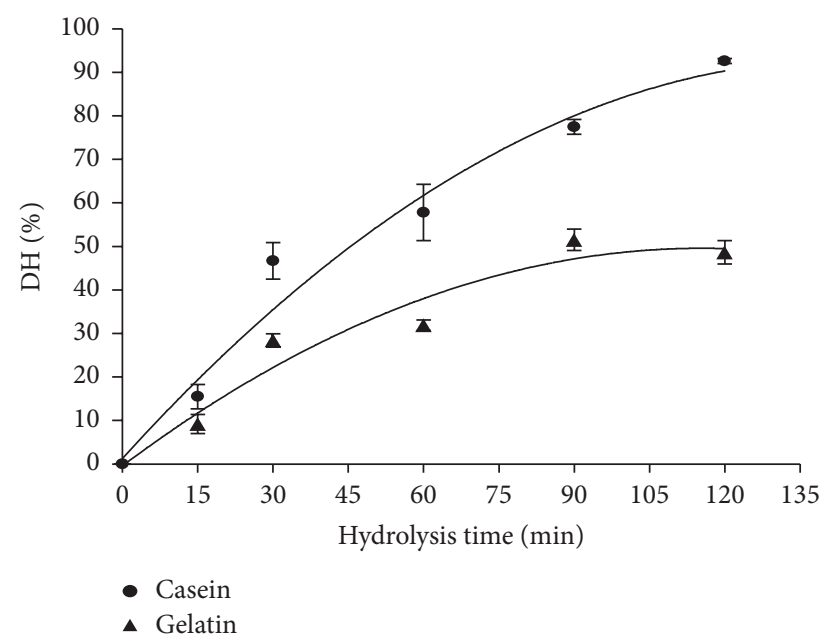

(a)

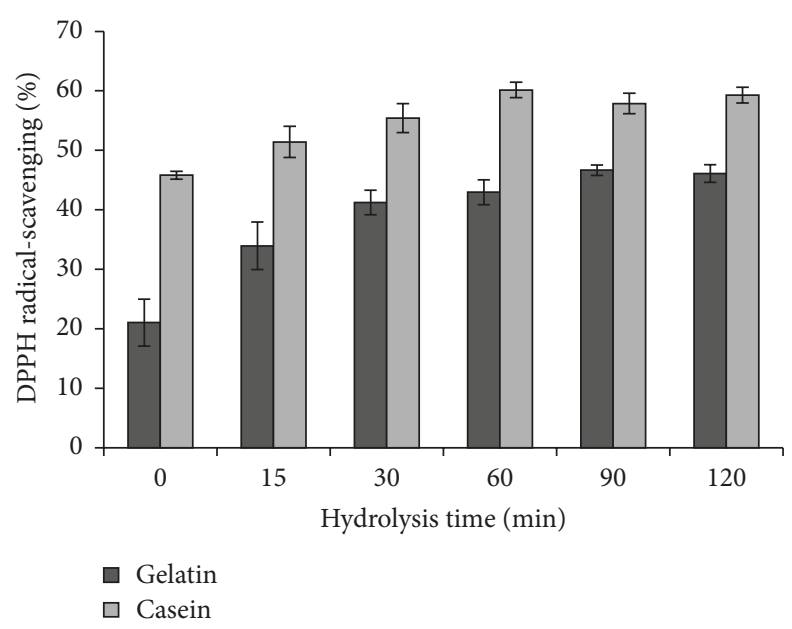

(b)

Figure 6: Hydrolysis and antioxidant activity assay. (a) Degree of hydrolysis (DH) for casein and gelatin substrates using proteases from $A$. Sojae ATCC 20235. (b) DPPH radical-scavenging activity using the hydrolysates from casein and gelatin. The error bars correspond to three independent assays.

TABLE 4: Estimated molecular weights corresponding to the bands with proteolytic activity for each extract.

\begin{tabular}{|c|c|}
\hline Sample & Estimate $\mathrm{Mw}$ \\
\hline \multirow{3}{*}{4} & 32 \\
\hline & 29 \\
\hline & 22 \\
\hline \multirow{3}{*}{8} & 32 \\
\hline & 34 \\
\hline & 26 \\
\hline \multirow{4}{*}{9} & 92 \\
\hline & 85 \\
\hline & 33 \\
\hline & 23 \\
\hline \multirow{10}{*}{12} & 88 \\
\hline & 78 \\
\hline & 68 \\
\hline & 58 \\
\hline & 51 \\
\hline & 40 \\
\hline & 36 \\
\hline & 29 \\
\hline & 22 \\
\hline & 19 \\
\hline
\end{tabular}

than gelatin after fifteen minutes of hydrolysis reaction, reaching $95 \%$ of hydrolysis degree at $120 \mathrm{~min}$. Similar degree of hydrolysis values has been obtained for casein hydrolysis using an immobilized $A$. oryzae protease [42].

Likewise, the antioxidant activity was higher for casein hydrolysates than for gelatin hydrolysates obtained throughout all the hydrolysis time. However the major increase rate was registered for gelatin, possibly because of the rapid increase of small peptides production that ranged between 11 and $25 \mathrm{kDa}$ (Figure 6(b) and Supplementary Data 6). In this context it is important to mention that the initial higher $\mathrm{DPPH}$ radical-scavenging activity and the low increase rate observed for casein are due to partial hydrolysis (small peptides) present in the substrate at the initial time (Supplementary Data 6).

\section{Conclusions}

Based on the results obtained in this study we were able to find new Aspergillus species and strains with the ability of achieving high and intermediate levels of proteolytic activity. This is the first report for protease production under solid state fermentation for the strains A. oryzae NRRL 2217, A. flavipes NRRL 295, A. oryzae ICFC 8/12, A. giganteus NRRL 10, A. rhizopodus NRRL 6136, A. sojae NRRL 5595, and A. sojae ATCC 20235. It was determined that these strains exhibited maximum protease productivity within a short fermentation time using wheat bran as substrate, which significantly reduces the production costs. It is important to note that the crude extracts from $A$. sojae ATCC 20235, $A$. oryzae ICFC 8/12, A. flavipes NRRL 295, and A. giganteus NRRL 10, which presented the maximum levels of protease productivity, showed remarkable proteolytic activity in a wide range of $\mathrm{pH}$ and temperature. The extracts of $A$. flavipes NRRL 295 and A. sojae ATCC 20235 presented a notable stability under optimum $\mathrm{pH}$ and temperature values with a high half-life $(240 \mathrm{~min})$. Likewise, these extracts showed a minimal $Q_{10}$ and $E_{\mathrm{a}}$ values for azo-casein hydrolysis. However, the proteolytic extract from A. sojae ATCC 20235 presented a high affinity for azo-casein. Finally, this extract is composed of a variety of proteolytic enzymes of different molecular weights and proved to be an appropriate biocatalyst for hydrolysis of casein and gelatin, increasing the antioxidant activities in 35\% and 125\%, respectively. 
In conclusion, A. sojae ATCC 20235 is a promising strain for the production of proteolytic enzymes useful for obtaining peptides from food by-products with nutritional and medicinal relevance.

\section{Conflict of Interests}

The authors declare that they have no conflict of interests in the research.

\section{Authors' Contribution}

Diego Gabriel Noseda and Edgardo Albertó equally contributed to this work as co-senior authors.

\section{Acknowledgments}

The work was supported by the PICT Start Up 2010-1312 grant from the National Agency for Science and Technology Promotion from the National Ministry of Science and Technology of Argentina (issued to Dr. E. Albertó). The authors would like to acknowledge Dr. Fernandez-Lahore (Jacobs University Bremen, Germany) for generously providing A. sojae ATCC 20235 strain. The RNNL strains employed in this work were kindly provided by ARS Culture Collection.

\section{References}

[1] V. Ramakrishna, S. Rajasekhar, and L. S. Reddy, "Identification and purification of metalloprotease from dry grass pea (Lathyrus sativus L.) seeds," Applied Biochemistry and Biotechnology, vol. 160, no. 1, pp. 63-71, 2010.

[2] N. P. Nirmal, S. Shankar, and R. S. Laxman, "Fungal proteases: an overview," International Journal of Biotechnology \& Biosciences, vol. 1, no. 1, 2011.

[3] R. J. Soares de Castro and H. H. Sato, "Production and biochemical characterization of protease from Aspergillus oryzae: an evaluation of the physical-chemical parameters using agroindustrial wastes as supports," Biocatalysis and Agricultural Biotechnology, vol. 3, no. 3, pp. 20-25, 2014.

[4] C. Li, D. Xu, M. Zhao, L. Sun, and Y. Wang, "Production optimization, purification, and characterization of a novel acid protease from a fusant by Aspergillus oryzae and Aspergillus niger," European Food Research and Technology, vol. 238, no. 6, pp. 905917, 2014.

[5] D. Heerd, S. Yegin, C. Tari, and M. Fernandez-Lahore, "Pectinase enzyme-complex production by Aspergillus spp. in solidstate fermentation: a comparative study," Food and Bioproducts Processing, vol. 90, no. 2, pp. 102-110, 2012.

[6] R. R. da Silva, T. P. de Freitas Cabral, A. Rodrigues, and H. Cabral, "Production and partial characterization of serine and metallo peptidases secreted by Aspergillus fumigatus Fresenius in submerged and solid state fermentation," Brazilian Journal of Microbiology, vol. 44, no. 1, pp. 235-243, 2013.

[7] A. Pandey, "Solid-state fermentation," Biochemical Engineering Journal, vol. 13, no. 2-3, pp. 81-84, 2003.

[8] A. Pandey, C. R. Soccol, and D. Mitchell, "New developments in solid state fermentation: I-bioprocesses and products," Process Biochemistry, vol. 35, no. 10, pp. 1153-1169, 2000.
[9] S. Y. Sun and Y. Xu, "Membrane-bound 'synthetic lipase' specifically cultured under solid-state fermentation and submerged fermentation by Rhizopus chinensis: a comparative investigation," Bioresource Technology, vol. 100, no. 3, pp. 1336$1342,2009$.

[10] I. A. Cavello, R. A. Hours, and S. F. Cavalitto, "Bioprocessing of 'hair waste' by Paecilomyces lilacinus as a source of a bleachstable, alkaline, and thermostable keratinase with potential application as a laundry detergent additive: characterization and wash performance analysis," Biotechnology Research International, vol. 2012, Article ID 369308, 12 pages, 2012.

[11] A. Riffel, F. Lucas, P. Heeb, and A. Brandelli, "Characterization of a new keratinolytic bacterium that completely degrades native feather keratin," Archives of Microbiology, vol. 179, no. 4, pp. 258-265, 2003.

[12] U. K. Laemmli, "Cleavage of structural proteins during the assembly of the head of bacteriophage T4," Nature, vol. 227, no. 5259, pp. 680-685, 1970.

[13] V. Neuhoff, N. Arold, D. Taube, and W. Ehrhardt, "Improved staining of proteins in polyacrylamide gels including isoelectric focusing gels with clear background at nanogram sensitivity using Coomassie Brilliant Blue G-250 and R-250," Electrophoresis, vol. 9, no. 6, pp. 255-262, 1988.

[14] I. A. Cavello, M. Chesini, R. A. Hours, and S. F. Cavalitto, "Study of the production of alkaline keratinases in submerged cultures as an alternative for solid waste treatment generated in leather technology," Journal of Microbiology and Biotechnology, vol. 23, no. 7, pp. 1004-1014, 2013.

[15] C. A. Schneider, W. S. Rasband, and K. W. Eliceiri, "NIH Image to ImageJ: 25 years of image analysis," Nature Methods, vol. 9, no. 7, pp. 671-675, 2012.

[16] M. Melikoglu, C. S. K. Lin, and C. Webb, "Kinetic studies on the multi-enzyme solution produced via solid state fermentation of waste bread by Aspergillus awamori," Biochemical Engineering Journal, vol. 80, pp. 76-82, 2013.

[17] R. J. Soares de Castro, A. Ohara, T. G. Nishide, J. R. M. Albernaz, M. H. Soares, and H. H. Sato, "A new approach for proteases production by Aspergillus niger based on the kinetic and thermodynamic parameters of the enzymes obtained," Biocatalysis and Agricultural Biotechnology, vol. 4, no. 2, pp. 199207, 2015

[18] A. Bougatef, M. Hajji, R. Balti, I. Lassoued, Y. Triki-Ellouz, and M. Nasri, "Antioxidant and free radical-scavenging activities of smooth hound (Mustelus mustelus) muscle protein hydrolysates obtained by gastrointestinal proteases," Food Chemistry, vol. 114, no. 4, pp. 1198-1205, 2009.

[19] J. Adler-Nissen, "Determination of the degree of hydrolysis of food protein hydrolysates by trinitrobenzenesulfonic acid," Journal of Agricultural and Food Chemistry, vol. 27, no. 6, pp. 1256-1262, 1979.

[20] P. M. Nielsen, D. Petersen, and C. Dambmann, "Improved method for determining food protein degree of hydrolysis," Journal of Food Science, vol. 66, no. 5, pp. 642-646, 2001.

[21] R. J. Soares de Castro, T. G. Nishide, and H. H. Sato, "Production and biochemical properties of proteases secreted by Aspergillus niger under solid state fermentation in response to different agroindustrial substrates," Biocatalysis and Agricultural Biotechnology, vol. 3, no. 4, pp. 236-245, 2014.

[22] R. J. Soares de Castro and H. H. Sato, "Synergistic effects of agroindustrial wastes on simultaneous production of protease and $\alpha$-amylase under solid state fermentation using a simplex 
centroid mixture design," Industrial Crops and Products, vol. 49, pp. 813-821, 2013.

[23] R. J. Soares de Castro and H. H. Sato, "Advantages of an acid protease from Aspergillus oryzae over commercial preparations for production of whey protein hydrolysates with antioxidant activities," Biocatalysis and Agricultural Biotechnology, vol. 3, no. 3, pp. 58-65, 2014.

[24] A. Belmessikh, H. Boukhalfa, A. Mechakra-Maza, Z. GheribiAoulmi, and A. Amrane, "Statistical optimization of culture medium for neutral protease production by Aspergillus oryzae. Comparative study between solid and submerged fermentations on tomato pomace," Journal of the Taiwan Institute of Chemical Engineers, vol. 44, no. 3, pp. 377-385, 2013.

[25] M. Hiyama, T. Ohmoto, M. Shinozuka, K. Ito, M. Iizuka, and N. Minamiura, "A serine proteinase of a fungus isolated from dried bonito 'Katsuobushi," Journal of Fermentation and Bioengineering, vol. 80, no. 5, pp. 462-466, 1995.

[26] C. G. Boer and R. M. Peralta, "Production of extracellular protease by Aspergillus tamarii," Journal of Basic Microbiology, vol. 40, no. 2, pp. 75-81, 2000.

[27] K. S. Vishwanatha, A. G. Appu Rao, and S. A. Singh, "Characterisation of acid protease expressed from Aspergillus oryzae MTCC 5341," Food Chemistry, vol. 114, no. 2, pp. 402-407, 2009.

[28] C. R. Tremacoldi, R. Monti, H. S. Selistre-De-Araújo, and E. C. Carmona, "Purification and properties of an alkaline protease of Aspergillus clavatus," World Journal of Microbiology and Biotechnology, vol. 23, no. 2, pp. 295-299, 2007.

[29] S. Germano, A. Pandey, C. A. Osaku, S. N. Rocha, and C. R. Soccol, "Characterization and stability of proteases from Penicillium sp. produced by solid-state fermentation," Enzyme and Microbial Technology, vol. 32, no. 2, pp. 246-251, 2003.

[30] I. I. Sutar, M. C. Srinivasan, and H. G. Vartak, "A low molecular weight alkaline proteinase from Conidiobolus coronatus," Biotechnology Letters, vol. 13, no. 2, pp. 119-124, 1991.

[31] S. Shenolikar and K. J. Stevenson, "Purification and partial characterization of a thiol proteinase from the thermophilic fungus Humicola lanuginosa," The Biochemical Journal, vol. 205, no. 1, pp. 147-152, 1982.

[32] S. Nasuno, "Differentiation of Aspergillus sojae from Aspergillus oryzae by polyacrylamide gel disc electrophoresis," Journal of General Microbiology, vol. 71, no. 1, pp. 29-33, 1972.

[33] M. Hajji, S. Kanoun, M. Nasri, and N. Gharsallah, "Purification and characterization of an alkaline serine-protease produced by a new isolated Aspergillus clavatus ES1," Process Biochemistry, vol. 42, no. 5, pp. 791-797, 2007.

[34] S. K. Chakrabarti, N. Matsumura, and R. S. Ranu, "Purification and characterization of an extracellular alkaline serine protease from Aspergillus terreus (IJIRA 6.2)," Current Microbiology, vol. 40, no. 4, pp. 239-244, 2000.

[35] S.-L. Wang, Y.-H. Chen, C.-L. Wang, Y.-H. Yen, and M.-K. Chern, "Purification and characterization of a serine protease extracellularly produced by Aspergillus fumigatus in a shrimp and crab shell powder medium," Enzyme and Microbial Technology, vol. 36, no. 5-6, pp. 660-665, 2005.

[36] H.-C. R. Chien, L.-L. Lin, S.-H. Chao et al., "Purification, characterization, and genetic analysis of a leucine aminopeptidase from Aspergillus sojae," Biochimica et Biophysica Acta (BBA)Gene Structure and Expression, vol. 1576, no. 1-2, pp. 119-126, 2002.

[37] X. Sun, E. Salih, F. G. Oppenheim, and E. J. Helmerhorst, "Kinetics of histatin proteolysis in whole saliva and the effect on bioactive domains with metal-binding, antifungal, and woundhealing properties," The FASEB Journal, vol. 23, no. 8, pp. 26912701, 2009.

[38] I. E. Crompton and S. G. Waley, "The determination of specificity constants in enzyme-catalysed reactions," Biochemical Journal, vol. 239, no. 1, pp. 221-224, 1986.

[39] P. S. Murthy and M. Naidu, "Protease production by Aspergillus oryzae in solid," World Applied Science Journal, vol. 2, no. 8, pp. 199-205, 2010.

[40] H. J. Kim, K. H. Park, J. H. Shin et al., "Antioxidant and ACE inhibiting activities of the rockfish Sebastes hubbsi skin gelatin hydrolysates produced by sequential two-step enzymatic hydrolysis," Fisheries and Aquatic Science, vol. 14, no. 1, pp. 1-10, 2011.

[41] R. J. Soares de Castro and H. H. Sato, "Protease from Aspergillus oryzae: biochemical characterization and application as a potential biocatalyst for production of protein hydrolysates with antioxidant activities," Journal of Food Processing, vol. 2014, Article ID 372352, 11 pages, 2014.

[42] S.-J. Ge, H. Bai, H.-S. Yuan, and L.-X. Zhang, "Continuous production of high degree casein hydrolysates by immobilized proteases in column reactor," Journal of Biotechnology, vol. 50, no. 2-3, pp. 161-170, 1996. 

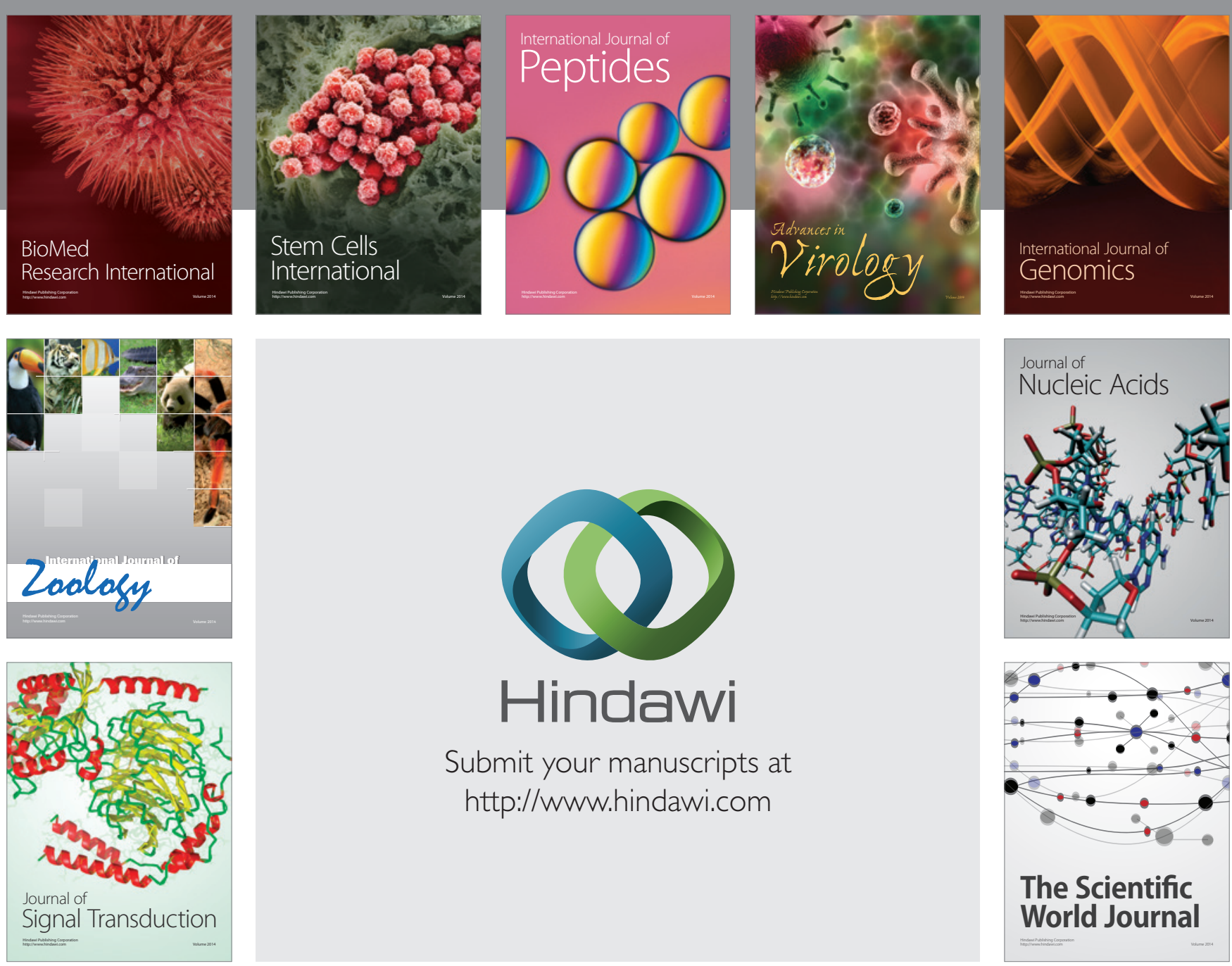

Submit your manuscripts at

http://www.hindawi.com
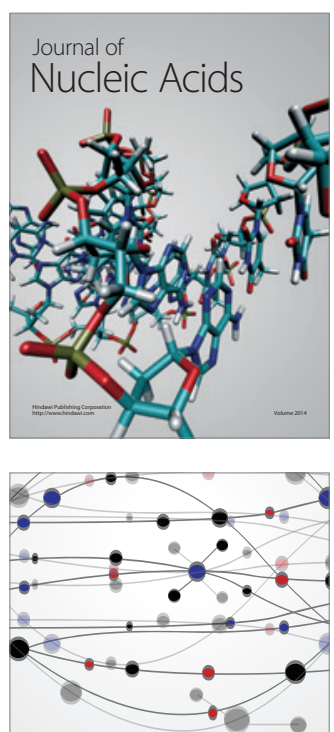

The Scientific World Journal
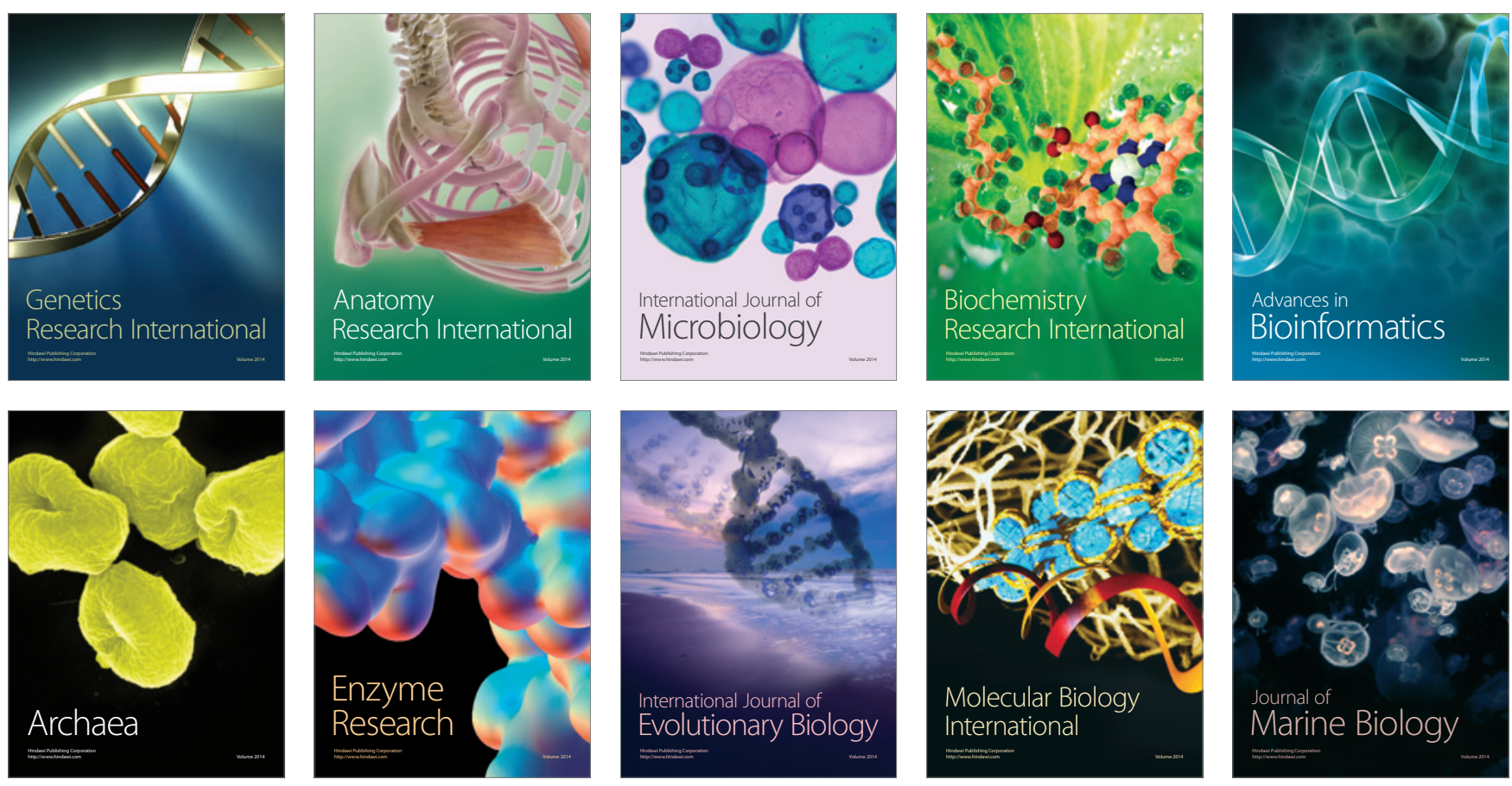